\title{
Peter og mig, vi gik i biografen. Paratagmer i ekstraposition i dansk
}

\author{
Eva Skafte Jensen
}

\begin{abstract}
This paper presents a study on the distribution of the case forms in personal pronouns used in dislocated coordinated conjuncts in Danish. Based on previous work on case distribution, coordinated conjuncts and dislocated pronouns, it is expected that pronouns will appear in the oblique form. This is tested empirically against a large corpus of coordinated conjuncts in spoken Danish. However, the results of the test do not satisfy the expectations. This prompts considerations on the nature of grammar in spoken language with reference to Auer's (2009) notion of 'on-line syntax', and it also gives occasion to revisit the dependency relations between the entities in NP's such as Peter og mig 'Peter and me'.
\end{abstract}

\section{Nøgleord}

dansk, ekstraposition, kasus, paratagmer, talt sprog

Denne artikel handler om kasusdistributionen ved paratagmer der står i ekstraposition. Anledningen er en empirisk undersøgelse af kasusdistributionen i paratagmer i dansk (se også Jensen 2018b, under udg.). Til hver af faktorerne nævnt i artiklens første sætning knytter sig en egen problemstilling som kunne give stof til en længere afhandling: Hvad er vilkårene for kasusdistributionen i dansk, hvordan kan og bør man analysere paratagmer, og hvordan skal man forstå ekstraposition? Det ligger udenfor rammerne af denne artikel at gøre noget sådant. Det er dog nødvendigt at give en kortfattet skitse over de tre faktorer for at kunne følge på hvilken måde de hver især bidrager til den problemstilling der er emnet for denne artikel. Artiklen er derfor opbygget således at der først gøres rede for de for artiklen relevante 
punkter ved de tre faktorer (kasusdistribution, paratagmer, ekstraposition) hver især og derpå peges på hvilke forventninger kombinationen af de tre faktorer afstedkommer. Endelig afprøves disse forventninger empirisk, og resultaterne af den empiriske afprøvning rejser nye spørgsmål, som efterfølgende diskuteres.

\section{Kasusdistributionen i dansk}

Moderne dansk er et såkaldt 'kasusfattigt' sprog (Sigurðsson 2006; Jensen 2018a, under udg.), dvs. et sprog hvor der kun er få kasus, og hvor disse kasus kun bliver anvendt ved et begrænset antal pronomener (andre kasusfattige sprog er fx svensk og engelsk). Konkret drejer det sig for dansks vedkommende om 7 personlige pronomener, der kan bøjes i to kasus, som vist $\mathrm{i}$ tabel 1 :

\begin{tabular}{|l|l|l|l|l|l|l|l|}
\hline & \multicolumn{4}{|l|}{ singularis } & pluralis \\
\hline & $1 \mathrm{p}$ & $2 \mathrm{p}$ & $3 \mathrm{pm}$ & $3 \mathrm{pf}$ & $1 \mathrm{p}$ & $2 \mathrm{p}$ & $3 \mathrm{p}$ \\
\hline nominativ & jeg & $d u$ & han & hun & $v i$ & $I$ & de \\
\hline oblik & mig & dig & ham & hende & os & jer & dem \\
\hline
\end{tabular}

Tabel 1 .

Morfologisk er der altså tale om et ret enkelt system med kun to former. Distributionen af de to former er dog knap så enkel. I korthed kan det siges at der findes en hovedregel, ifølge hvilken nominativ bruges ved subjekt, og oblik form bruges i alle andre funktioner; men der findes også en del særregler, hvoraf nogle sætter hovedreglen ud af spil, og andre resulterer i valgmulighed mellem de to former. Af hensyn til fremstilingen og til omfanget af artiklen er det ikke muligt at gå i dybden med alle detaljer her (se i stedet fx Jacobsen \& Jørgensen 1988: 122-128, Hansen 1993: 57-62, Jensen, under udg. og referencer heri). I denne artikel vil blikket være rettet mod den del af særreglerne der har direkte indflydelse på paratagmer og på ekstraposition.

I en artikel fra 1972 beskriver Erik Hansen hvordan der ved siden af hovedreglen eksisterer en alternativ regel, hvorefter pronomener der optræder i funktioner hvor de er obligatorisk trykstærke, står i oblik form, mens de i funktioner hvor de både har mulighed for at være trykstærke og tryksvage (og i deres umarkerede brug er tryksvage), står i nominativ (se også Brink \& Lund 1975: 663 f.). I visse tilfælde resulterer hovedreglen og trykstyrkereglen 
i samme kasus, fx når det pågældende pronomen fungerer som prædikativ, jf. (1), hvor pronomenet er trykstærkt og ikke fungerer som subjekt, ergo bruges oblik form, mig. I andre tilfælde resulterer de to regler i forskellige kasus, fx når et pronomen indgår i et paratagme der fungerer som subjekt, jf. (2), hvor pronomenet er trykstærkt (oblik form ifølge trykstyrkereglen, mig), og hvor det indgår i et subjekt (nominativ ifølge hovedreglen, jeg):

\section{(1) det er mig}

(2) Peter og mig/jeg skal i biografen

Heltoft har også arbejdet med fænomenet, og særligt i en række artikler fra 1990'erne nuancerer han Hansens observationer med semantiske karakteristikker (se fx Heltoft 1991, 1992). Ifølge Heltoft finder man ved siden af hovedreglen ganske rigtigt en alternativ regel, en regel hvorefter distributionen ved subjekt reguleres efter informationsstrukturelle forhold. De subjektspronomener der prototypisk er tryksvage, er i praksis sådanne hvor koblingen mellem udtrykket (selve pronomenet) og den referent der tales om, er sikret deiktisk eller ana-/kataforisk. Ved 1. og 2. person, og i visse tilfælde ved 3. person, vil det af situationen fremgå hvem det pågældende pronomen henviser til; i givet fald beror identifikationen af referenten på deiktiske forhold. Ved 3. person kan det også fremgå af den tidligere eller efterfølgende tekst hvem pronomenet henviser til; i givet fald beror identifikationen af referenten på ana- eller kataforiske forhold. I alle disse tilfælde tjener tilstedeværelsen af et pronomen til på minimal vis at sikre identifikation af referent og at sikre kohæsion. Hvis et subjektspronomen derimod ledsages af en specificerende tilføjelse (fx en relativsætning eller et adverbial, jf. (3) - (4)) eller et sideordnet led, jf. (5), udviser det ikke mere den minimale referencemåde. ${ }^{1}$ I sådanne tilfælde kan man ifølge Hansens og Heltofts alternative regel vente oblik form.

$$
\begin{aligned}
& \text { ham der bor på tredje, er venlig } \\
& \text { ham på tredje er venlig } \\
& \text { Lise og mig gik i biografen }
\end{aligned}
$$

I praksis betyder dette at subjektspronomener der ikke ledsages af yderligere materiale, står i nominativ, mens de står i oblik form i andre tilfælde (se oversigt Hansen \& Heltoft 2011: 438-443).

1 Den minimale referencemåde for en entitet der udgør en flerhed, er et pluralt pronomen, jf. $\boldsymbol{v} \boldsymbol{i}$ gik $\mathrm{i}$ biografen. Bemærk at pronomenet i givet fald står i nominativ. 
At der ved praktisk sprogudøvelse forekommer både nominativ og oblik form i paratagmer der fungerer som subjekt (jf. (2) og (5)), beror altså på at der blandt sprogbrugerne er to regler i spil på en og samme tid: hovedreglen og den alternative trykstyrke-/informationsstrukturregel. I tilfælde som (3) og (4) er den alternative regel ikke længere i konkurrence med hovedreglen (jf. også Brink \& Lund 1975: 668); i tilfælde som (5) er den alternative regel netop i konkurrence med hovedreglen, og sprogbrugerne har da mulighed for at anvende den ene eller den anden regel; nogle sprogbrugere har formodentlig begge regler indlejret i deres sprogsystem og vil dermed kunne veksle mellem nominativ og oblik form i paratagmer (se også Hansen \& Heltoft 2011: 440, pkt. 5).

Analysen er kompatibel med Jørgensens (2000) analyse af nominativ som den form der bruges ved pronomener der findes i funktioner med affinitet til baggrund (fx subjekt), og oblik form som den form der bruges ved pronomener der findes i funktioner med affinitet til fokus (fx objekt og prædikativ).

I denne sammenhæng er det væsentligt at hæfte sig ved at man ved subjektsparatagmer ikke bør overraskes over at se såvel nominativ som oblik form repræsenteret, for ved paratagmer finder man oblik form brugt i alle syntaktiske funktioner, inkl. subjekt; tendensen til at bruge oblik form i subjektsparatagmer er dog væsentlig stærkere i talt sprog end i skrevet sprog (Jensen 2018b, under udg.). Nominativ finder man ifølge eksisterende beskrivelser derimod kun ved subjekt. ${ }^{2}$ Disse forhold fører i nogle fremstillinger til en karakteristik af oblik form som default, altså som den form der bruges hvis ikke tungtvejende grunde tilsiger nominativ, og hvis der for eksempel er uklarhed om syntaktisk funktion (se fx Brink \& Lund 1975: 663-664).

\section{Paratagmer}

Der er en solid tradition for at analysere syntagmer som Peter og Lise som sideordningsforbindelser hvor to eller flere led på samme syntaktiske niveau koordineres ved hjælp af en konjunktion, prototypisk og, eller eller men (jf.

2 Der er særlige omstændigheder knyttet til og jeg. Den ordrette streng og jeg (ikke jeg og, ikke $0 g$ han ...) kan tilsyneladende bruges i alle funktioner. I Jensen 2018b og under udg. argumenteres der for at der ikke er tale om en egentlig kasusbrug ved netop denne streng, men at og jeg i stedet skal ses som en holofrase eller en 'readymade', dvs. en samlet enhed hvor de enkelte dele ikke lader sig analysere hver især. 
fx Mikkelsen 1911: 476 f.; Diderichsen 1946: 142, 1952; Hansen 1967(1): 174 f.; Dik 1968: 25; Hansen 1977: 63-64; Jensen 1985: 38; Sweetser 1990; Hansen \& Heltoft 2011: 281-283, 440; se også Jensen, under udg.). Sideordning kan foregå på alle sproglige niveauer fra sproghandlinger over sætninger til sætningsled og morfemer (Sweetser 1990: 86-112).

Et vigtigt argument for analysen er at de to led kan byttes rundt uden at den samlede denotative betydning ændrer sig. Rent denotativt betyder (6) det samme som (7):

(6) Peter og Lise gik i biografen

(7) Lise og Peter gik i biografen

Et andet argument er at en enkelt af de sideordnede størrelser kan varetage samme funktion som hele den samlede sideordningsforbindelse. I (8) varetager Peter den samme funktion (subjekt) som Lise og Peter i (7) ovenfor:

(8) Peter gik i biografen

Ved siden af denne tradition finder man en anden, hvorefter syntagmer som Peter og Lise analyseres som henholdsvis kerne og adled, altså en hypotaktisk struktur (se fx Dik 1968 og referencer heri; Bærentzen 1989; Johannessen 1998: 46 f., 237 f.; se også Hansen \& Heltoft 2011: 440). De to analyser skildres af Dik (1968: 52) som i (10) og (11):

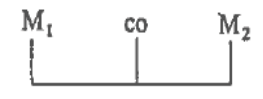

(11)

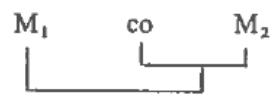

Dette vil blive diskuteret videre $i$ afsnit 6 .

\section{Ekstraposition}

Ekstraposition i dansk er et fænomen som langtfra er udtømmende undersøgt og beskrevet, på trods af at det er meget udbredt. Delaspekter er behandlet i Mikkelsen 1911: 741-743, Diderichsen 1945: 13 f., 1946: 194 f., Togeby 
2003: 101, 174, Brøcker mfl. 2012: 25-28, Bak 2014: 93 f., Johannessen 2014, Jørgensen 2013, 2016, Christensen 2017. Den tilsyneladende mest udførlige redegørelse hvor fænomenet inklusive det konstruktionsmæssige, det topologiske og det funktionelle potentiale knyttet til de forskellige placeringsmuligheder søges beskrevet, finder man i Grammatik over det Danske Sprog (Hansen \& Heltoft 2011: 1827-1841). Fremstillingen herefter følger især denne beskrivelse, men bygger også på indsigter fra de andre nævnte kilder.

I Grammatik over det Danske Sprog står der:

Ekstraposition er en konstruktion hvor et led med funktion inden for en sætning placeres uden for denne sætnings normale placeringsramme. Det ekstraponerede led er repræsenteret ved et pronomen eller et andet anaforisk eller kataforisk led inden for sætningen. Dette led angiver det ekstraponerede leds relation til og funktion i sætningen og skal stå på en plads der er mulig for det ekstraponerede led (Hansen \& Heltoft 2011: 1827).

Fænomenet består altså i en bestemt type fordobling af sætningsled. ${ }^{3}$ Selve termen ekstraposition er særligt knyttet til en danskfaglig tradition hvor den topologiske model (sætningsskemaet) bidrager til forståelsesrammen for sætningsanalyse (herunder ledstilling og konstituentanalyse). I andre faglige traditioner kan man finde termen 'dislokering', men den grundlæggende erkendelse er den samme: Et led kan i det lineære forløb være repræsenteret to gange; den ene gang på sin normale plads indenfor sætningen, den anden gang på en dertil indrettet plads udenfor sætningen. Nominale led såvel som adverbielle led kan ekstraponeres. I det følgende samles opmærksomheden om nominale led.

Hvad angår materiale, er den repræsentation af nominale led man finder indenfor sætningen, pronominal, jf. citatet ovenfor. Den repræsentation der står udenfor sætningen (det ekstraponerede led), er ofte informativt tungere, hvilket også fremgår af de eksempelsamlinger man finder i fremstillinger om ekstraposition (Diderichsen 1946: 194 f., 1945: 13 f.; Hansen \& Heltoft 2011: 1827 f.; Bak 2014: 93 f.). I (12) - (13) gives nogle få eksempler cite-

3 En anden type er apposition, se fx Schack 2016. I ældre fremstillinger skelnes der ikke altid tydeligt mellem dette og ekstraposition, se fx Hansen 1965: 100.

4 I Brøcker mfl. (2012: 26, med henvisning til et foredrag af Jakob Steensig) bruges målet "alle syntagmer, der er større end pronominer og småadverbier". 
ret efter Hansen \& Heltoft (2011: 1827, 1829); det ekstraponerede led er fremhævet med fed skrift, mens den pronominale repræsentation indenfor sætningen er understreget:

(12) Christian den Anden, han lagde ikke fingrene imellem

(13) postbuddet, hende har jeg lige set køre forbi

Det er dog ikke sådan at det ekstraponerede led ikke kan være et pronomen, se fx (14): ${ }^{5}$

ham, han er en skat

I fremstillinger om ekstraposition på dansk gives som minimum altid eksempler som dem der er vist i (12) - (14), dvs. eksempler på venstreponerede led i sætninger med deklarativ ledstilling. Men dette dækker kun en begrænset del af mulighederne. I det følgende gives en ultrakort oversigt over flere muligheder (se mere udførlige redegørelser i Hansen \& Heltoft 201 1: 18271841). Det skal tages med i betragtning at der på dansk er to forskellige ledstillingsmønstre (det deklarative og det neutrale ledstillingsmønster, jf. Hansen \& Heltoft 2011: 1569 f.), ${ }^{6}$ og at der både kan ekstraponeres fra sætninger efter det deklarative og efter det neutrale mønster. Desuden kan man ekstraponere både til venstre og til højre for sætningen. Dette gør at man kan finde en del flere ekstrapositionspladser end den mest kendte (som er den der demonstreres i (12) - (14) ovenfor); eksemplerne (15) - (20) er fra Hansen \& Heltoft (2011: 1828, 1829, 1833):

(15) Merete ved du om hun kommer med (venstreposition, neutralt ledstillingsmønster)

(16) ved du om Merete hun kommer med (venstreposition, neutralt ledstillingsmønster)

5 Johannessen (2014) misforstår Hansen \& Heltoft når hun hævder at de skriver at pronomener ikke kan ekstraponeres; Hansen \& Heltoft påpeger at dette kun gælder en særlig slags pronominal brug, nemlig den de kalder 'anaforisk', den som udløser nominativ. De giver selv eksemplet $\boldsymbol{d e m}$, de afleverer altid til tiden på ekstraponeret pronomen (Hansen \& Heltoft 2011: 1830).

6 I den ældre tradition taler man ofte om hoved- vs. bisætningsledstilling (se fx Diderichsen 1946). Ledstillingsmønstrene er dog ikke knyttet særskilt til de to sætningstyper, men kan bruges på tværs af disse. Derfor taler Hansen \& Heltoft (2011: 1563-1569) i stedet om deklarativt hhv. neutralt ledstillingsmønster. 
(17) mon hovedbygningen den også er brændt (venstreposition, neutralt ledstillingsmønster)

(18) Han kom til at tænke på dengang de tog til Bretagne, ham og Kissen og Christine (højreposition, neutralt ledstillingsmønster) (19) Den bliver jo ødelagt på den måde, låsen (højreposition, deklarativt ledstillingsmønster)

(20) De er ikke så dyre, jordbærrene, på denne tid af året (højreposition, deklarativt ledstillingsmønster)

Ved venstreposition i sætninger med neutralt ledstillingsmønster er der to muligheder: Dels kan et led ekstraponeres til en plads foran sætningsskemaets ordinære pladser, som i (15) (ligesom i sætninger som (12) - (14)), dels til en plads umiddelbart til venstre for subjektet som i (16) - (17). Ved højreposition kan et led ekstraponeres til en plads til højre for sætningskernen (dvs. til højre for verbalet og dets styrede led, Hansen \& Heltoft 2011: 285) som i (18) - (20). Et højreekstraponeret led kan således stå længst til højre for sætningen som i (18) og (19), men det kan også være placeret inden eventuelle frie led som i (20). Der er med andre ord mange steder i det lineære forløb hvor et ekstraponeret led kan stå.

Det særlige ved ekstraposition er altså at der sker en fordobling af et sætningsled. Når man vil forklare hvorfor dette sker, tager man typisk udgangspunkt i en antagelse om at den dobbelte benævnelse har en særlig funktion. Denne funktion forklares ofte informationsstrukturelt, som for eksempel at man ved ekstraponering "udpeger [...] et emne som eksplicit tema i modsætning til andre mulige" (Hansen \& Heltoft 2011: 1836). Ved fordoblingen aktiveres således den paradigmatiske akse: Der rejses en forventning om at der kunne være andre størrelser der kunne være relevante i den givne sammenhæng, og ved ekstraponering til venstre gør man klart at de andre er mindre relevante, uden at man ligefrem kontrasterer dem (Jørgensen 2016: 283, 296). Om ekstraponering til højre skriver Hansen \& Heltoft (2011: 1837) at dette ofte har karakter af "improvisation". I (18) - (20) kunne man kalde det præcisering, i andre tilfælde kan der være tale om emotive udsagn, fx han skulle som sedvanlig gøre sig klog, professoren (Hansen \& Heltoft 2011: 1838).

Brøcker mfl. (2012) påpeger at det i samtaler er langt mere almindeligt at lave fordobling end ikke at gøre det (de undersøger venstreponerede led). Faktisk er det så almindeligt at det der kræver forklaring, er omstændighederne for hvornår et led $i k k e$ fordobles. Dette er tilsyneladende tilfældet når et led er nævnt tidligere i samtalen eller er situationelt givet. I andre tilfælde 
- og de er altså de hyppigste - er det almindeligt at nævne en referent to gange: ved ekstraponering og inden i sætningen. Dette er kompatibelt med Hansen \& Heltofts forklaring.

I litteraturen om ekstraposition nævnes det ikke eksplicit hvordan det forholder sig med kasusbrugen ved ekstraponerede pronomener, men ud fra de ganske få eksempler der gives, kan man se at forventningen her er at sådanne vil stå i oblik form (Hansen 1965: 100; Hansen 1967(2): 243; Brink \& Lund 1975: 669; Hansen \& Heltoft 2011: 1830; Jørgensen 2016: 286). Dette er i overensstemmelse med hvad man ville forvente i forlængelse af de to forrige afsnit, nemlig at pronomener der ikke er subjekt i en sætning, vil stå i oblik form.

\section{Sammenfatning: kasusformer i paratagmer i eks- traposition}

Ud fra redegørelserne i de forudgående afsnit vil man vente at personlige pronomener i paratagmer i ekstraposition i dansk står i oblik form: I alle andre syntaktiske funktioner end subjekt kræver hovedreglen oblik form. Desuden er det almindeligt med oblik form i paratagmer, uanset syntaktisk funktion. De eneste steder hvor nominativ altid er obligatorisk, er ved pronomener der fungerer som subjekt, og hvor identifikationen af hvilken referent pronomenet repræsenterer, alene fremgår deiktisk (1., 2. og 3. person) eller ana-/kataforisk (3. person). Et sådant pronomen vil altid være uledsaget af et specificerende adled eller en sideordnet størrelse.

\section{Empirisk efterprøvning}

Forventningen om oblik form afprøves på en datasamling bestående af 677 paratagmer i ekstraposition indeholdende mindst ét personligt pronomen. De 677 paratagmer er fra talesprogskorpusset ved Danmarks Grundforskningsfonds Center for Sociolingvistiske Sprogforandringsstudier ved Københavns Universitet (også kaldet LANCHART-korpusset). Korpusset er på ca. 10 mio. løbende ord, og det består af transskriberinger af sociolingvistiske interview fra talere i mange dele af Danmark gennem 4 årtier. De tidligste interview er fra 1980'erne, de seneste er fra 2015. I dette korpus er samtlige paratagmer blevet søgt frem og analyseret med hensyn til syntaktisk funktion og kasusform. I sin helhed blev der etableret en datasamling på 2262 paratagmer i alle syntaktiske funktioner. Af disse stod de 677 altså i ekstraposition. En mere fuldstændig rapport for materiale, for metodiske refleksioner og 
for de andre syntaktiske funktioner for paratagmerne kan læses i Jensen, under udg. Som sagt er forventningen til paratagmer i ekstraposition nu at pronomener vil stå i oblik form, men som det fremgår af tabel 2, bliver denne forventning ikke fuldt indfriet:

\begin{tabular}{|c|c|c|c|c|c|}
\hline \multirow[b]{2}{*}{$\mathrm{sg}$} & & nomina & & oblik & \\
\hline & \multirow[t]{2}{*}{$1 p$} & og jeg & 161 & og mig & 115 \\
\hline & & jeg og & 5 & mig og & 177 \\
\hline & \multirow[t]{2}{*}{$2 p$} & $o g d u$ & 12 & og dig & 17 \\
\hline & & $d u \circ g$ & 16 & dig $o g$ & 42 \\
\hline & \multirow[t]{2}{*}{$3 \mathrm{pm}$} & og han & 0 & og ham & 11 \\
\hline & & han og & 6 & ham og & 42 \\
\hline & \multirow[t]{2}{*}{$3 \mathrm{pf}$} & og hun & 1 & og hende & 8 \\
\hline & & hun og & 0 & hende og & 24 \\
\hline \multirow[t]{7}{*}{ pl } & \multirow[t]{2}{*}{$1 p$} & $o g v i$ & 0 & og os & 1 \\
\hline & & vi $o g$ & 3 & os og & 0 \\
\hline & \multirow[t]{2}{*}{$2 p$} & $o g I$ & 0 & og jer & 1 \\
\hline & & $\operatorname{Iog}$ & 0 & jer og & 0 \\
\hline & \multirow[t]{2}{*}{$3 p$} & $o g d e$ & 1 & og dem & 29 \\
\hline & & de og & 3 & dem og & 2 \\
\hline & & & 208 & & 469 \\
\hline
\end{tabular}

Tabel 2.

Allerflest uventede nominativer finder man ved strengen og jeg. Disse bør dog ikke nødvendigvis alle sammen tages som udtryk for kasus i klassisk (eller moderne!) forstand. Som vist andetsteds (Jensen 2018b; under udg.) opfører netop denne streng sig så aparte at man ikke med sikkerhed kan regne jeg netop her for en ægte kasusform. ${ }^{7}$ Men selv hvis man ikke tager alle disse og jeg-forekomster alvorligt som udtryk for kasus, er der stadig alt for mange nominativforekomster til at man kan sige at forventningen om oblik form ved paratagmer i ekstraposition er indfriet.

Det vil selvfølgelig være fristende at frasortere dem: Måske er der simpelthen tale om at databehandlingen og kategoriseringen af materialet har været mangelfuld; måske er der slet ikke tale om ekstraposition ved de forekomster der i tabel 2 viser sig i nominativ. Men forekomster fra datasamlingen som (21) og (22) ligner på alle måder ganske almindelige ekstraponeringer som dem der er vist tidligere i artiklen:

$7 \quad$ Se også note 2. 
(21) jeg og [N N] vi går til gymnastik i Holstebro

(22) er I jævnaldrende du og din kone

Dette har nu ledt til nærmere overvejelser om paratagmer, om ekstraposition og om talt sprog. Det handler resten af artiklen om.

\section{Talesprog, ekstraposition og paratagmer}

Ekstraposition bliver ofte karakteriseret som et overvejende talesprogligt fænomen, ${ }^{8}$ og det er derfor oplagt at undersøge fænomenet i talt sprog. Dog viser det sig at der netop ved talt sprog er forhold der udfordrer analyserne af fænomenet. Det vigtigste er at man danner sin tale mens man taler (Steensig 2001: 72-75, 90 f.; Auer 2009; Puggaard 2018). Auer kalder dette fænomen for 'on-line syntax'. ${ }^{9}$

For den der producerer tale, gælder det om at gøre sig forståelig; for den der lytter, gælder det om at forstå.

For den der skal producere talen, kan det være en fordel at benytte sig af grammatiske enheder der i udgangspunktet rummer mange muligheder for videre udviklinger. For eksempel påpeger Puggaard (2018; under udg.) i en undersøgelse af brugen af fundamentfeltet på dansk at der her er en overhyppighed af ordet det, og at dette formodentlig skyldes at netop ordet det har et stort syntaktisk potentiale, og at det dermed giver taleren mange muligheder for at bevæge sig videre ad de veje ordet tilbyder (Puggaard 2018: 62; under udg.).

For den der lytter, er opgaven at følge med, og ud fra sin erfaring med strukturerne i det sprog der tales, vil vedkommende holde sin tolkning af det sagte åben indtil det viser sig hvordan det syntaktisk lægger sig til rette.

Auer (2009: 5) giver blandt andet eksemplet i (23), som er relevant både ud fra et produktionsperspektiv og et forståelsesperspektiv (der citeres tegnret fra Auer; hver anden linje er den engelske oversættelse af det originalt tyske):

$\begin{array}{lll}\text { in der }(-) & \text { gegend } & \text { von toRONto } \rightarrow \\ \text { in the } & \text { region } & \text { of Toronto } \\ \text { leben } & \text { wenig } & \text { Frankophone } \\ \text { live } & \text { few } & \text { French speakers }\end{array}$

8 På trods af at det vist aldrig er blevet systematisk efterprøvet om der er forskel på tale og skrift på dette punkt, se også Brøcker mfl. 2012: 26 og Jørgensen 2016: 283.

9 Foruden 'on-line syntax' finder man termer som 'emergent grammar' og 'inkrementel' grammatik. 
Ifølge Auer ville det der står i første tyske linje, sagtens kunne udvikle sig til det der står i anden tyske linje. Men det gør det ikke (Auer 2009: 7). I stedet udvikler det sig til det der citeres i (24):

\begin{tabular}{|c|c|c|c|}
\hline \multirow{2}{*}{$\begin{array}{l}\text { in der }(-) \\
\text { in the }\end{array}$} & gegend von & toRONto & da (.) \\
\hline & region of & Toronto & ART \\
\hline bissl & wEstlich & davon, & \\
\hline a little & to-the-west & of-it & \\
\hline$=$ also & in Waterloo & & \\
\hline that-is & in Waterloo & & \\
\hline$=(\mathrm{w}) \mathrm{O}(-)$ & .h auch ne (-) b & NNte universiTÄT & isch $(-)$ \\
\hline where & also a well-1 & n university & is \\
\hline $\begin{array}{l}\text { da: }(1.0) \\
\text { there }(1.0)\end{array}$ & $\begin{array}{l}\text {.h leben ja noch } \\
\text {.h still live a }\end{array}$ & $\begin{array}{l}\text { nze REIhe dieser; } \\
\text { lot of these; (-) An }\end{array}$ & $\begin{array}{l}\text { Amish peop } \\
\text { h people }\end{array}$ \\
\hline
\end{tabular}

Det relevante i denne sammenhæng er at syntagmet in der gegend von Toronto i (23) fungerer adverbielt, mens det i (24) står i ekstraposition. En ytring er ikke nødvendigvis planlagt færdig i alle detaljer inden selve fremsigelsen af den, men bygger på elementer som undervejs i et forløb tilpasses den sproglige og interaktionelle situation man befinder sig i. En ytring vokser frem mens den fremsiges.

\subsection{Talesprog, ekstraposition og kasus}

Nogle af datasamlingens nominativer har ikke nødvendigvis på forhånd været planlagt som noget der skulle stå i ekstraposition. Ekstraponeringen kan så at sige være sket som en del af det processuelle i og med at ytringen tager form. Dette kan for eksempel sagtens være tilfældet med (21) ovenfor. Det ville ikke være svært at forestille sig at paratagmet jeg og $[\mathcal{N} \mathcal{N}]$ ikke ligefrem har været planlagt som et ekstraponeret led. Sætningen kunne sagtens have udviklet sig som i (25), hvor jeg og $[\mathcal{N} \mathcal{N}]$ slet og ret er et subjekt, og hvor nominativ ville have været helt almindeligt:

$$
\text { jeg og [N N] går til gymnastik i Holstebro }
$$

Et lignende eksempel fra min datasamling vises i (26), hvor ytringen snildt kunne have udviklet sig anderledes end citeret, nemlig uden pronomenet $v i$, hvorved paratagmet (med pronomenerne i nominativ) ville have udgjort subjekt: 

antistofpositive

Pointen her er ikke at nominativerne er 'forkerte' fordi taleren først har lagt sig syntaktisk fast undervejs i forløbet og jo i sagens natur ikke kan gå tilbage og rette. Pointen er at en grammatisk enhed, som for eksempel et nominalparatagme, i udgangspunktet er fleksibel med hensyn til syntaktisk funktion. I Auers eksempel har dette ikke konsekvens for morfologien, men det har det for de danske eksempler med paratagmer der indeholder et personligt pronomen. For i sådanne tilfælde er man nødt til at vælge mellem to forskellige kasusformer.

Det er almindeligt at anse oblik form for defaultkasus, dvs. den kasus man kan bruge hvis der ikke er tungtvejende grunde til at bruge nominativ (jf. afsnit 1). Set fra et procesperspektiv giver det dog god mening at lægge ud med pronomener i nominativ. Alt andet lige indgår pronomener tidligt i en ytring ofte i subjekter (jf. fx Jørgensen 2013: 184; Puggaard 2018: 21 f., under udg.), og disse kan jo som fremlagt i afsnit 1 godt stå i nominativ. Hvis dette er tilfældet, lirker det ved karakteristikken af oblik form som default. Schack (2013: 66) nuancerer da også denne karakteristik idet han skriver: "Et pronomen med ikke-tydelig ledfunktion er friere stillet med hensyn til kasus".

\subsection{Talesprog og paratagmer}

Endnu et punkt hvor idéen om on-line syntax giver anledning til eftertanke, er ved selve forståelsen af paratagmer. Som nævnt i afsnit 2 er der en stærk tradition for at anse leddene i et syntagme som Peter og Lise for sideordnede (det ligger i selve termen para-tagme at der er tale om parallelle størrelser). Der findes dog som tidligere nævnt også en anden tradition, hvorefter leddene i sådanne syntagmer ikke anses for sideordnede men for kerne og adled i en hypotaktisk struktur.

Ved nogle af paratagmerne i datasamlingen ser det ud til at disse dannes undervejs i forløbet, som fx i (27):

... ikke undre mig fordi at byens snobber de øh de og deres børn de kom også derind

Her lægges der ud med byens snobber, dette nominal ekstraponeres i og med brugen af pronomenet $d e$, og dette efterfølges af et $ø h$. Dette $ø h$ kan signalere en tøven brugt til at forme det videre forløb. Efter $ø$ g gentages de og udvides 
med og deres børn. Ifølge Steensig (2001) og Auer (2009) er udvidelser særdeles almindelige i dagligdags tale. I den forstand er der tale om et fuldstændig ordinært fænomen, grænsende til det banale. Spørgsmålet er om man skal drage en teoretisk konsekvens af dette og anse og deres børn som en tilføjelse med en anden status end et sideordnet led.

Hos Hansen \& Heltoft (2011: 440) finder man faktisk en sådan karakteristik som en af to ${ }^{10}$ mulige analyser: "... paratagmet opfattes som en pronominalform der specificeres gennem det andet led. På indholdssiden er forholdet specifikation, altså en form for hypotakse". Hansen \& Heltoft opererer med en skarp skelnen mellem dependensforhold på indholdssiden hhv. på udtrykssiden (i fremstillingen tydeligst gennemført ved analysen af nominalsyntagmer, som på indholdssiden bliver analyseret som katatagmer, og på udtrykssiden som hypotagmer, jf. Hansen \& Heltoft 201 1: 273-276, 547-548).

Der er dog, så vidt jeg kan skønne, problemer med analysen både på udtryks- og indholdssiden. På udtrykssiden er problemet ved at analysere et

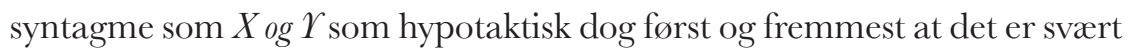
at se hvordan $\mathcal{Y}$ skulle være et adled til $X$. I klassisk kerne-adled-analyse er adleddet underordnet kerneleddet; der er med andre ord en udtrykssyntaktisk relation mellem de to led hvor det ene led (adleddet) er underordnet det andet (kerneleddet). Som følge af dette skulle man vente at et af de to led i syntagmet ham og hans kone $\mathrm{i}$ (28) var syntaktisk underordnet det andet:

hans kone og ham de bor i Dragør

Det er dog ikke indlysende at ham skulle være adled til hans kone (og heller ikke - for nu at afprøve den omvendte mulighed - at hans kone skulle være adled til ham).

Indholdssyntaktisk er analysen også svær at se for sig. I klassisk kerne-adledanalyse specificerer adleddet kerneleddet (jf. også Hansen \& Heltoft-citatet); i for eksempel syntagmet meget tret får vi gennem meget en specificering af trætheden. Det er svært at se hvordan hans kone er en specificering af ham i hans kone og ham (eller omvendt).

I stedet kan man fastholde at der i tilfælde som de og deres børn, hans kone og ham, du ogjeg og lignende faktisk er tale om paratagmer - og netop med

10 Den anden er at tolke de to entiteter i et syntagme som Ole og jeg som to ligestillede led, fx to sideordnede subjekter (Hansen \& Heltoft 2011: 440). 
henvisning til de processer der gør sig gældende ved talt sprog: Når man ytrer sig, har man ikke nødvendigvis på forhånd besluttet sig for at det der skal komme ud ad munden på én, er et paratagme eller ej. Dette er noget der formes on-line i og med at man former sin ytring. Men når ytringen så faktisk er formuleret, er et syntagme som $d u$ og din kone for det analytiske øje et paratagme bestående af sideordnede led.

Måske netop på grund af den umiddelbart ukomplicerede syntaktiske relation der er mellem leddene i et paratagme, kan man føje en i princippet uendelig række af ekstra led til det første som vist i følgende selvproducerede eksempel:

(29) kan du ikke købe nogle abler ... og to mælk ... og noget smør ... og rødbeder ...

Netop deri består det særlige ved paratagmer, og når nogle af dem i talt sprog virker som rækker af ad hoc-tilføjelser, kan det skyldes at de netop er rækker af (sideordnede) ad hoc-tilføjelser.

\subsection{Kasus ved paratagmer $i$ ekstraposition}

Hvad angår kasus i paratagmer i ekstraposition, giver materialet i denne undersøgelse ikke anledning til at fastslå at sådanne står i oblik form snarere end i nominativ. I stedet ser det ud til at Schacks formulering at pronomener ved visse ledfunktioner "er friere stillet med hensyn til kasus", holder stik. Det er med andre ord muligt at bruge nominativ såvel som oblik form ved paratagmer der ekstraponeres.

\section{Konklusion}

I denne artikel fremlægges resultaterne af et delstudie der indgår i et større projekt om kasusdistributionen i danske personlige pronomener (se bl.a. Jensen 2018ab, Jensen, under udg. og Schack, Jensen \& Petersen 2019. I delstudiet undersøges særligt brugen af kasus ved pronomener i paratagmer der står i ekstraposition. Der rejses en forventning om at den upåfaldende brug i denne type grammatiske sammenhæng vil være oblik form, men et stort antal forekomster fra et talesprogskorpus kan ikke uden videre bekræfte noget sådant. Tværtimod er en så stor del af forekomsterne i nominativ at det er nødvendigt at se nærmere på dem.

En nøgle til forståelse viser sig at ligge i selve det at datasamlingen består af talt sprog. Det er en grundlæggende erkendelse i samtaleanalysen at 
sætninger og ytringer produceres on-line, altså stort set i det øjeblik de fremsiges. Det at de produceres samtidig med at de fremsiges, kan resultere i at de udvikler sig undervejs i frembringelsen. En enhed kan i udgangspunktet være åben for brug (fx som et adverbial eller som noget andet) og finder først sin endelige funktion i det faktiske forløb (fx som et ekstraponeret led). Tilsvarende kan et paratagme i udgangspunktet tolkes som noget der vil kunne være subjekt, men falder undervejs i frembringelsen på plads som ekstraponeret led.

Erkendelsen af at talesprogssyntaks er noget der udvikler sig mens det frembringes, viser sig også at have indflydelse på hvordan vi kan forstå den indre opbygning af paratagmer.

Om kasusvalget må det konkluderes at man ved pronomener der indgår i paratagmer i ekstraposition, kan finde både nominativ og oblik form i faktisk sprogbrug.

\section{Om forfatteren}

Eva Skafte Jensen, dr.phil., seniorforsker ved Dansk Sprognævn.

\section{Referencer}

Auer, P. (2009): On-line syntax. Thoughts on the temporality of spoken language. Language Sciences 31, 1-13.

Bak, S.M. (2014): En sammenlignende undersogelse af syntaktiske trak i middelnedertyske diplomer fra Lübecks kancelli og det kongelige danske kancelli (1400-1449). Ph.d.-afhandling, Københavns Universitet.

Brink, L. \& J. Lund (1975): Dansk rigsmål, lydudviklingen siden 1840 med serligt henblik på sociolekterne $i$ København. København: Gyldendal.

Brøcker, K.K., M.G.T. Hamann, M.Jørgensen, S.B. Lange, N.H. Mikkelsen \& J. Steensig (2012): Samtalesprogets grammatik - fire fænomener og nogle metodiske overvejelser. $\mathcal{N} y$ danske Studier 42, 10-40.

Bæhrentzen, P. (1989): Syntaktische Subklassifizierung der Fügewörter im Deutschen. I: Sprechen mit Partikeln. H. Weydt (red.). Berlin \& New York: Walter de Gruyter, 19-29.

Christensen, S.J. (2017): Om så og der som genoptagere for ekstraponerede tid- og stedsadverbialer. I: Ny forskning i grammatik. Fallespublikation 24. Jakobsen, L.F., Kragh,K.J., Lindschouw, J. \& Strudsholm, E. (red.). København: Dansk Sprognævn, 107-120. 
Diderichsen, P. (1945): Dansk Sætningsanalyse. Dens Formaal og Metode. Nydanske Studier 16-17, 1986, 7-17.

Diderichsen, P. (1946): Elementer Dansk Grammatik. 3. udg. København: Gyldendal 1987.

Diderichsen, P. (1952): De tre hovedarter af grammatisk forbindelse. I: Helhed og struktur. Udvalgte Sprogvidenskabelige Afhandlinger. København: Gad 1966, 192-208.

Dik, S. (1968): Coordination. Its implications for the theory of general linguistics. Amsterdam: North-Holland Publishing Company.

Hansen, A. (1965): Vort vanskelige sprog. København: Grafisk forlag.

Hansen, A. (1967): Moderne Dansk 1-3. København: Grafisk forlag.

Hansen, E. (1972): Dr. Jekyll og Mr. Hyde i Dansk Grammatik. En filologisk skitse. I: Gleden ved grammatik. Udvalgte artikler og afhandlinger. Jacobsen, H.G. \&Jørgensen, H. (red.). København: Hans Reitzels Forlag, 2001, 98-110.

Hansen, E. (1977): Demonernes port. 3. udg. København: Reitzel 1984.

Hansen, E. (1993): Rigtigt dansk. 2. udg. København: Hans Reitzels Forlag. Hansen, E. \& L. Heltoft (2011): Grammatik over det Danske Sprog. Odense \& København: Syddansk Universitetsforlag \& Det Danske Sprog- og Litteraturselskab.

Heltoft, L. (1991): Talesprogets tale. Møde om Udforskningen af Dansk Sprog $3,126-143$.

Heltoft, L. (1992): Topologiens plads i en sprogteori. Sprogvidenskabelige arbejdspapirer fra Kobenhavns Universitet 2, 67-98.

Jacobsen, H. G. \& P. S. Jørgensen (1988): Håndbog i Nudansk. 6. udg. København: Politikens Forlag 2013.

Jensen, E.S. (2018a): It is me - the replacement of the nominative by the oblique form in Danish subject complements. Acta Linguistica Hafniensia $50(1), 1-21$.

Jensen, E.S. (2018b): Norm, usus og korpus. Kasusvalg i paratagmer. I: Dansk til det 21. Arhundrede - sprog og samfund. Christensen, T.K., Fogtmann, C. Jensen, T.J., Karrebæk, M.S., Maegaard, M., Pharao, N. \& Quist, P. (red.). København: U Press, 171-182.

Jensen, E.S. (under udg.): Gitte og mig - kasus i paratagmer i moderne dansk talesprog. Danske talesprog.

Jensen, P.A. (1985): Principper for grammatisk analyse. København: Nyt Nordisk Forlag Arnold Busck.

Johannessen, J.B. (1998): Coordination. Oxford: Oxford University Press.

Johannessen, J.B. (2014): Left dislocation in main and subordinate clauses. Nordic Atlas of Language Structures (NALS) Fournal 1, 406-414. 
Jørgensen, H. (2000): Studien zur Morphologie und Syntax der festlandskandinavischen Personalpronomina - mit besonderer Berücksichtigung des Dänischen. Aarhus: Aarhus University Press.

Jørgensen, H. (2013): Sætningsspidsens udfyldning - observationer fra et talesprogsmateriale. I: Ny forskning i grammatik. Fallespublikation 20. Jakobsen, L.F., Kragh, K.J., Jensen, E.S. \& Strudsholm, E. (red.). København: Dansk Sprognævn, 183-202.

Jørgensen, H. (2016): Doubling left syntactic positions in Danish. I: Let us have articles betwixt us - Papers in Historical and Comparative Linguistics in Honour of Johanna L. Wood. S. Vikner, H. Jørgensen \& E.v. Gelderen (red.). Århus: Dept. of English, School of Communication \& Culture, Aarhus University, 281-298.

Mikkelsen, K. (191 1): Dansk ordföjningslare med sproghistoriske tillag. København: Hans Reitzel, genoptryk 1974.

Puggaard, R. (2018): The function of the foundation field in Danish talk-in-interaction. Upubl. kandidatspeciale. Aarhus Universitet.

Puggaard, R. (under udg.): Flexibility of frequent clause openers in talk-ininteraction. Det and så in the prefield in Danish. Nordic fournal of Linguistics.

Schack, J. (2013): Dig og mig og vi to. Synspunkter på kasus i moderne dansk. Nydanske Sprogstudier 45, 48-72.

Schack, J. (2016): Appositionsforbindelser. I: Ny forskning i grammatik. Fallespublikation 23. Christensen, M.H., Heltoft, L., Jensen, E.S., Mortensen, S.S., Nielsen, P.J. \& Petersen, J.H. (red.). København: Dansk Sprognævn, 217-232.

Schack, J., E.S. Jensen \& J.H. Petersen (2019): Tak til alle de der gor en indsats for vores sikkerhed. Bagom dronningens kasusvalg. I: Møde om Udforskningen af Dansk Sprog 16. Schoonderbeek, I. \& Hougaard, T.T. (red.). Århus, 443-456.

Sigurðsson, H.Á. (2006): The Nom/Acc alternation in Germanic. I: Comparative Studies in Germanic Syntax. Hartmann, J.M. \& Molnárfi, L. (red.). Amsterdam: John Benjamins, 15-50.

Steensig, J. (2001): Sprog i virkeligheden. Bidrag til en interaktionel lingvistik. Århus: Aarhus Universitetsforlag.

Sweetser, E.E. (1990): From etymology to pragmatics. Metaphorical and cultural aspects of semantic strucure. Cambridge: Cambridge University Press.

Togeby, O. (2003): Fungerer denne satning? Funktionel dansk satningslare. København: Gad. 